\title{
When Work Disappears: New Implications for Race and Urban Poverty in the Global Economy
}

\author{
William Julius Wilson
}

\section{Contents}

Introduction

Inner-City Jobless Poverty

Explanations of the Growth of Inner-City Jobless Poverty

Public Policy Challenges

Addressing Jobless Poverty in the Face of the New Racism

How the Situational Context influences Public Policy Discussions of Jobless Poverty Conclusion

References

CASEpaper

CASE/17

November 1998
Centre for Analysis of Social Exclusion

London School of Economics

Houghton Street

London WC2A 2AE

CASE enquiries: tel: 01719556679 


\section{Centre for Analysis of Social Exclusion}

The ESRC Research Centre for Analysis of Social Exclusion (CASE) was established in October 1997 with funding from the Economic and Social Research Council. It is located within the Suntory and Toyota International Centres for Economics and Related Disciplines (STICERD) at the London School of Economics and Political Science, and benefits from support from STICERD. It is directed by Howard Glennerster, John Hills, Kathleen Kiernan, Julian Le Grand and Anne Power.

Our Discussion Papers series is available free of charge. We also produce summaries of our research in CASEbriefs. To subscribe to the series, or for further information on the work of the Centre and our seminar series, please contact the Centre Administrator, Jane Dickson, on:

Telephone: $\quad$ UK+1719556679

Fax: $\quad$ UK+171 2422357

Email: $\quad$ j.dickson@lse.ac.uk

Web site: $\quad$ http://sticerd.lse.ac.uk/case.htm

(C) William Julius Wilson

All rights reserved. Short sections of text, not to exceed two paragraphs, may be quoted without explicit permission provided that full credit, including (C) notice, is given to the source. 


\section{Editorial Note}

William Julius Wilson is the Malcolm Wiener Professor of Social Policy and Director of the Joblessness and Urban Poverty Research Program at the Malcolm Wiener Center for Social Policy, John F. Kennedy School of Government, Harvard University. He was a visitor to CASE in June and July 1998 when he gave the Ethnic and Racial Studies/London School of Economics 1998 Public Lecture, in association with CASE. This paper formed the basis of his lecture, and will be published in the journal Ethnic and Racial Studies, 22(3), May 1999.

\section{Abstract}

This paper discusses the impact of growing joblessness and dwindling work opportunities on inner-city areas in America. The lack of low-skilled manual work in the inner city is linked to poverty, crime, family dissolution and the social life of neighbourhoods. The paper discusses this impact at a neighbourhood-wide, family and individual level, noting the interaction between these levels and the intergenerational repercussions that result.

The paper goes on to look at race in this context, identifying a new form of cultural racism. It examines the way race becomes an issue as black people become disproportionately represented in neighbourhoods where there is a high ratio of joblessness and very few work opportunities. The paper shows how this segregation plus its interaction with other changes in society, escalates rates of neighbourhood joblessness and compounds existing problems in these neighbourhoods.

Finally the paper examines the role of public policy, the way it has exacerbated inner-city joblessness and how it attempted to resolve the problem, but failed. The paper concludes by pointing to a way forward to improve work opportunities for all sectors of society that are struggling to make ends meet, including the inner-city poor and the working- and middleclasses. 


\section{Introduction}

It is a pleasure to return to the LSE to address an issue that I care deeply about, the decreased relative demand for low-skilled labour and its implications for the urban poor and race relations. In drawing out this issue, I want, in the first part of my lecture, to highlight some of the main arguments raised in my latest book, When Work Disappears (1996). And then in the second part of my lecture I want to discuss how to shape the policy debate in United States and Britain so that the problems of the low-skilled labour force, including the low-skilled minority labour force, are not isolated from those that stem from global economic change.

\section{Inner-City Jobless Poverty}

There is a new poverty in American metropolises that has consequences for a range of issues relating to the quality of life in urban areas, including race relations. By the 'new urban poverty', I mean poor, segregated neighbourhoods in which a majority of individual adults are either unemployed or have dropped out or never been a part of the labour force. This jobless poverty today stands in sharp contrast to previous periods. In 1950, a substantial portion of the urban black population in the United States was poor but they were working. Urban poverty was quite extensive but people held jobs. However, as we entered the 1990s most poor adults were not working in a typical week in the ghetto neighbourhoods of America's larger cities. For example, in 1950 a significant majority of adults held jobs in a typical week in the three neighbourhoods that represent the historic core of the Black Belt in the city of Chicago - Douglas, Grand Boulevard and Washington Park - the three neighbourhoods of Chicago that received the bulk of black migrants from the South in the early to mid-twentieth century. But by 1990 only four in ten in Douglas worked in a typical week, 1 in 3 in Washington Park, and 1 in 4 in Grand Boulevard. In 1950, 69 percent of all males 14 and over who lived in these three neighbourhoods worked in a typical week, and in 1960, 64 percent of this group were so employed. However, by 1990 only 37 percent of all males 16 and over held jobs in a typical week in these three neighbourhoods.

The disappearance of work has adversely affected not only individuals and families, but the social life of neighbourhoods as well. Inner-city joblessness in America is a severe problem that is often overlooked or obscured when the focus is mainly on poverty and its consequences. Despite increases in the concentration of poverty since 1970, inner cities in the United 
States have always featured high levels of poverty, but the levels of inner-city joblessness reached during the first half of the 1990s was unprecedented.

I should note that when I speak of 'joblessness' I am not solely referring to official unemployment. The unemployment rate, as measured in the United States, represents only the percentage of workers in the official labour force - that is, those who are actively looking for work. It does not include those who are outside of or have dropped out the labour market, including the nearly 6 million males 25 to 60 who appeared in the census statistics but were not recorded in the labour market statistics in 1990 (Thurow 1995).

These uncounted males in the labour market are disproportionately represented in the inner-city ghettos. Accordingly, in my book, When Work Disappears (1996), I use a more appropriate measure of joblessness that takes into account both official unemployment and non-labour-force participation. That measure is the employment-to-population ratio, which corresponds to the percentage of adults 16 and older who are working. Using the employment to population ratio we find, for example, that in 1990 only one in three adults ages 16 and older held a job in the ghetto poverty areas of Chicago, areas with poverty rates of at least 40 percent and that represent roughly 425,000 men, women and children. And in the ghetto census tracts of the nation's 100 largest cities for every 10 adults who did not hold a job in a typical week in 1990 there were only 6 employed persons (Kasarda 1993).

The consequences of high neighbourhood joblessness are more devastating than those of high neighbourhood poverty. A neighbourhood in which people are poor, but employed, is much different from a neighbourhood in which people are poor and jobless. In When Work Disappears (1996) I attempt to show that many of today's problems in America's inner-city ghetto neighbourhoods - crime, family dissolution, welfare, low levels of social organisation and so on - are in major measures related to the disappearance of work.

It should be clear that when I speak of the disappearance of work, I am referring to the declining involvement in or lack of attachment to the formal labour market. It could be argued that in the general sense of the term 'joblessness' does not necessarily mean 'non-work.' In other words, to be officially unemployed or officially outside the labour market does not mean that one is totally removed from all forms of work activity. Many people who are officially jobless are nonetheless involved in informal kinds of work activity, ranging from unpaid housework to work in the informal or illegal economies that draw income.

Housework is work, baby-sitting is work, even drug dealing is work. However, what contrasts work in the formal economy with work activity in the informal and illegal economies is that work in the formal economy is 
characterised by, indeed calls for, greater regularity and consistency in schedules and hours. Work schedules and hours are formalised. The demands for discipline are greater. It is true that some work activities outside the formal economy also call for discipline and regular schedules. Several studies reveal that the social organisation of the drug industry in the United States is driven by discipline and a work ethic, however perverse (Bourgois 1995; Venkatesh 1996). However, as a general rule, work in the informal and illegal economies is far less governed by norms or expectations that place a premium on discipline and regularity. For all these reasons, when I speak of the disappearance of work, I mean work in the formal economy, work that provides a framework for daily behaviour because of the discipline, regularity, and stability that it imposes.

In the absence of regular employment, a person lacks not only a place in which to work and the receipt of regular income but also a coherent organisation of the present - that is, a system of concrete expectations and goals. Regular employment provides the anchor for the spatial and temporal aspects of daily life. It determines where you are going to be and when you are going to be there. In the absence of regular employment, life, including family life, becomes less coherent. Persistent unemployment and irregular employment hinder rational planning in daily life, a necessary condition of adaptation to an industrial economy (Bourdieu 1965).

Thus, a youngster who grows up in a family with a steady breadwinner and in a neighbourhood in which most of the adults are employed will tend to develop some of the disciplined habits associated with stable or steady employment - habits that are reflected in the behaviour of his or her parents and of other neighbourhood adults. These might include attachment to a routine, a recognition of the hierarchy found in most work situations, a sense of personal efficacy attained through the routine management of financial affairs, endorsement of a system of personal and material rewards associated with dependability and responsibility, and so on. Accordingly, when this youngster enters the labour market, he or she has a distinct advantage over the youngsters who grow up in households without a steady breadwinner and in neighbourhoods that are not organised around work - in other words, a milieu in which one is more exposed to the less disciplined habits associated with casual or infrequent work.

With the sharp recent rise of solo-parent families in the United States, black children who live in inner-city ghetto households are less likely to be socialised in a work environment for two main reasons. Their mothers, saddled with child-care responsibilities, can prevent a slide deeper into poverty by accepting welfare. Their fathers, removed from family responsibilities and obligations, are more likely to become idle as a response 
to restricted employment opportunities, which further weakens their influence in the household and attenuates their contact with the family. In short, the social and cultural responses to limiting constraints and changing norms are reflected in the organisation of family life and patterns of family formation; there they have implications for labour force attachment as well.

\section{Explanations of the Growth of Inner-City Jobless Poverty}

What accounts for the much higher proportion of jobless adults in America's inner-cities since the mid-twentieth century' An easy explanation would be racial segregation. However, a race-specific argument is not sufficient to explain recent changes in such neighbourhoods. After all, the historical black belt neighbourhoods that I just talked about were as segregated by skin colour in 1950 as they are today, yet the level of employment was much higher then. One has to account for the ways in which racial segregation interacts with other changes in society to produce the recent escalating rates of neighbourhood joblessness. Several factors stand out.

The disappearance of work in many inner-city neighbourhoods is in part related to the nation-wide decline in the fortunes of low-skilled workers. The sharp decline in the relative demand for unskilled labour has had a more adverse effect on blacks than on whites in the United States because a substantially larger proportion of African-Americans are unskilled. Although the number of skilled blacks (including managers, professionals and technicians) has increased sharply in the last several years, the proportion of those who are unskilled remains large, because the black population, burdened by cumulative experiences of racial restrictions, was overwhelmingly unskilled just several decades ago (Schwartzman 1997).

The factors involved in the decreased relative demand for unskilled labour include:

- the computer revolution (i.e., the spread of new technologies that displaced low-skilled workers and rewarded the more highly trained),

- the rapid growth in college enrolment that increased the supply and reduced the relative cost of skilled labour, and

- the growing internationalisation of economic activity, including trade liberalisation policies which reduced the price of imports and raised the output of export industries (Schwartzman 1997; Krueger 1997; Katz 1996).

Whereas the increased output of export industries aids skill workers, simply because skill workers are heavily represented in export industries, increasing 
imports, especially those from developing countries that compete with labour-intensive industries (for example, apparel, textile, toy, footwear and some manufacturing industries) hurt unskilled labour (Schwartzman 1997), and therefore would have significant negative implications for American black workers. For example, 40 percent of the workforce in the apparel industry is African-American.

But, inner-city workers in the United States face an additional problem - the growing suburbanisation of jobs. Most ghetto residents cannot afford an automobile and therefore have to rely on public transit systems that make the connection between inner-city neighbourhoods and suburban job locations difficult and time consuming.

Although studies based on data collected before 1970 showed no consistent or convincing effects on black employment as a consequence of this spatial mismatch, the employment of inner-city blacks relative to suburban blacks has clearly deteriorated since then. Recent research, conducted mainly by urban and labour economists, strongly shows that the decentralisation of employment is continuing and that employment in manufacturing, most of which is already suburbanised, has decreased in central cities, particularly in the Northeast and Midwest (Holzer 1991; Holzer, Ihlanfeldt, and Sjoquist 1994; Ihlanfeldt, Keith, and Sjoquist 1991; Zax and Kain 1992).

As pointed out in When Work Disappears, blacks living in central cities have less access to employment, as measured by the ratio of jobs to people and the average travel time to and from work, than do central-city whites. Moreover, unlike most other groups of workers across the urban/suburban divide, less educated central-city blacks receive lower wages than suburban blacks who have similar levels of education. And the decline in earnings of central-city blacks is related to the decentralisation of employment - i.e., the movement of jobs from the cities to the suburbs - in metropolitan areas.

Although the relative importance of the different underlying causes in the growing jobs problems of the less-skilled, including those in the inner city, continue to be debated, there is little disagreement about the underlying trends. They are unlikely to reverse themselves. In short, over a sustained period the labour market in the United States has twisted against disadvantaged workers - those with limited skills or education and/or from poor families and neighbourhoods - and therefore greatly diminished their actual and potential earnings (Katz 1996).

Changes in the class, racial, and demographic composition of inner-city neighbourhoods have also contributed to the high percentage of jobless adults in these neighbourhoods. Because of the steady outmigration of more advantaged families, the proportion of non-poor families and prime-age 
working adults has decreased sharply in the typical inner-city ghetto since 1970 (Wilson 1987). In the face of increasing and prolonged joblessness, the declining proportion of non-poor families and the overall depopulation have made it increasingly more difficult to sustain basic neighbourhood institutions or to achieve adequate levels of social organisation. The declining presence of working- and middle-class blacks has also deprived ghetto neighbourhoods of key resources, including structural resources, such as residents with income to sustain neighbourhood services, and cultural resources, such as conventional role models for neighbourhood children.

On the basis of our research in Chicago, it appears that what many high jobless neighbourhoods have in common is a relatively high degree of social integration (high levels of local neighbouring while being relatively isolated from contacts in the broader mainstream society) and low levels of informal social control (feelings that they have little control over their immediate environment, including the environment's negative influences on their children). In such areas, not only are children at risk because of the lack of informal social controls, they are also disadvantaged because the social interaction among neighbours tends to be confined to those whose skills, styles, orientations, and habits are not as conducive to promoting positive social outcomes (academic success, pro-social behaviour, employment in the formal labour market, etc.) as are those in more stable neighbourhoods. Although the close interaction among neighbours in such areas may be useful in devising strategies, disseminating information, and developing styles of behaviour that are helpful in a ghetto milieu (teaching children to avoid eye-to-eye contact with strangers and to develop a tough demeanour in the public sphere for self-protection), they may be less effective in promoting the welfare of children in the society at large.

Despite being socially integrated, the residents in Chicago's ghetto neighbourhoods share a feeling that they have little informal social control over the children in their environment. A primary reason is the absence of a strong organisational capacity or an institutional resource base that would provide an extra layer of social organisation in their neighbourhoods. It is easier for parents to control the behaviour of the children in their neighbourhoods when a strong institutional resource base exists and when the links between community institutions such a churches, schools, political organisations, businesses, and civic clubs are strong or secure. The higher the density and stability of formal organisations, the less illicit activities such as drug trafficking, crime, prostitution, and the formation of gangs can take root in the neighbourhood.

A weak institutional resource base is what distinguishes high jobless inner-city neighbourhood from stable middle-class and working-class areas. 
As one resident of a high-jobless neighbourhood on the South Side of Chicago put it:

Our children, you know, seems to be more at risk than any other children there is, because there's no library for them to go to. There's not a centre they can go to, there's no field house that they can go into. There's nothing. There's nothing at all.

Parents in high jobless neighbourhoods have a much more difficult task of controlling the behaviour of their adolescents, of preventing them from getting involved in activities detrimental to pro-social development. Given the lack of organisational capacity and a weak institutional base, some parents choose to protect their children by isolating them from activities in the neighbourhood, including the avoidance of contact and interaction with neighbourhood families. Wherever possible, and often with great difficulty when one considers the problems of transportation and limited financial resources, they attempt to establish contacts and cultivate relations with individuals, families and institutions outside the neighbourhood such as church groups, schools, and community recreation programmes.

It is just as indefensible to treat inner-city residents as super heroes who overcome racist oppression as it is to view them as helpless victims. We should, however, appreciate the range of choices, including choices representing cultural influences, that are available to inner-city residents who live under constraints that most people in the larger society do not experience.

In the eyes of employers in metropolitan Chicago, the social conditions in the ghetto render inner-city blacks less desirable as workers, and therefore many are reluctant to hire them. One of the three studies that provided the empirical foundation for When Work Disappears included a representative sample of employers in the greater Chicago area who provided entry-level jobs. An overwhelming majority of these employers, both white and black, expressed negative views about inner-city ghetto workers, and many stated that they were reluctant to hire them. For example, a president of an innercity manufacturing firm expressed a concern about employing residents from certain inner-city neighbourhoods:

If somebody gave me their address, uh, Cabrini Green I might unavoidably have some concerns. Interviewer: What would your concerns be? Respondent: That the poor guy probably would be frequently unable to get to work and...I probably would watch him more carefully even if it wasn't fair, than I would with somebody else. I know what I should do though is recognise that here's a guy that is trying to get out of his situation and probably 
will work harder than somebody else who's already out of there and he might be the best one around here. But I, I think I would have to struggle accepting that premise at the beginning.

In addition to qualms about the neighbourhood milieu of inner-city residents, the employers frequently mentioned concerns about applicants' language skills and educational training. An employer from a computer software firm in Chicago expressed the view that in many businesses the ability to meet the public is paramount and you do not talk street talk to the buying public. Almost all your black welfare people talk street talk. And who's going to sit them down and change their speech patterns?' A Chicago real estate broker made a similar point:

A lot of times I will interview applicants who are black, who are sort of lower class...They'll come to me and I cannot hire them because their language skills are so poor. Their speaking voice for one thing is poor...they have no verbal facility with the language....and these...you know, they just don't know how to speak and they'll say 'salesmens' instead of 'salesmen' and that's a problem...They don't know punctuation, they don't know how to use correct grammar, and they cannot spell. And I can't hire them. And I feel bad about that and I think they're being very disadvantaged by the Chicago Public School system.

Another respondent defended his method of screening out most job applicants on the telephone on the basis of their use of 'grammar and English'.

I have every right to say that that's a requirement for this job. I don't care if you're pink, black, green, yellow or orange, I demand someone who speaks well. You want to tell me that I'm a bigot, fine, call me a bigot. I know blacks, you don't even know they're black. So do you.

Finally, an inner-city banker claimed that many blacks in the ghetto 'simply cannot read. When you're talking our type of business, that disqualifies them immediately, we don't have a job here that doesn't require that somebody have minimum reading and writing skills.'

How should we interpret the negative attitudes and actions of employers? To what extent do they represent an aversion to blacks per se and to what degree do they reflect judgements based on the job- related skills and training of inner-city blacks in a changing labour market? I should point out that the statements made by the African-American employers concerning the qualifications of inner-city black workers do not differ significantly from 
those of the white employers. Whereas 74 percent of all the white employers who responded to the open-ended questions expressed negative views of the job-related traits of inner-city blacks, 80 percent of the black employers did so as well.

This raises a question about the meaning and significance of race in certain situations - in other words, how race intersects with other factors. A key hypothesis in this connection is that given the recent shifts in the economy, employers are looking for workers with a broad range of abilities: 'hard' skills (literacy, numeracy, basic mechanical ability, and other testable attributes) and 'soft' skills (personalities suitable to the work environment, good grooming, group-oriented work behaviours, etc.). While hard skills are the product of education and training - benefits that are apparently in short supply in inner-city schools - soft skills are strongly tied to culture, and are therefore shaped by the harsh environment of the inner-city ghetto. For example, our research revealed that many parents in the inner-city ghetto neighbourhoods of Chicago warned their children not to make eye to eye contact with strangers and to develop a tough demeanour when interaction with people on the streets. While such behaviours are helpful for survival in the ghetto they hinder successful interaction in mainstream society.

If employers are indeed reacting to the difference in skills between white and black applicants, it becomes increasingly difficult to discuss the motives of employers: are they rejecting inner-city black applicants out of overt racial discrimination or on the basis of qualifications?

Nonetheless, many of the selective recruitment practices do represent what economists call statistical discrimination: employers make assumptions about the inner-city black workers in general and reach decisions based on those assumptions before they have had a chance to review systematically the qualifications of an individual applicant. The net effect is that many black inner-city applicants are never given the chance to prove their qualifications on an individual level because they are systematically screened out by the selective recruitment process.

Statistical discrimination, although representing elements of class bias against poor workers in the inner city, is clearly a matter of race. The selective recruitment patterns effectively screen out far more black workers from the inner city than Hispanic or white workers from the same types of backgrounds. But race is also a factor, even in those decisions to deny employment to inner-city black workers on the basis of objective and thorough evaluations of their qualifications. The hard and soft skills among inner-city blacks that do not match the current needs of the labour market are products of racially segregated communities, communities that have 
historically featured widespread social constraints and restricted opportunities.

Thus the job prospects of inner-city workers have diminished not only because of the decreasing relative demand for low-skilled labour in the United States economy, the suburbanisation of jobs, and the social deterioration of ghetto neighbourhoods, but also because of negative employer attitudes.

\section{Public Policy Challenges}

The foregoing analysis suggest that the passage of the recent welfare reform bill in the United States, which did not include a programme of job creation, could have very negative social consequences in the inner city. Unless something is done to enhance the employment opportunities of inner-city welfare recipients who reach the time limit for the receipt of welfare, if the economy slows down they will flood a pool that will be already filled with low-skilled jobless workers.

New research into urban labour markets by the economist Harry Holzer (1996) of Michigan State University reveals the magnitude of the problem. Surveying 3,000 employers in Atlanta, Boston, Detroit and Los Angeles, Holzer found that only 5 to 10 percent of the jobs in central-city areas for workers who are non-college graduates require very few work credentials or cognitive skills. This means that most inner-city workers today not only need to have the basic skills of reading, writing, and performing arithmetic calculations, but need to know how to operate a computer as well. Also, most employers require a high school degree, particular kinds of previous work experience, and job references. Because of the large oversupply of low-skilled workers relative to the number of low-skilled jobs, many low-educated and poorly trained individuals have difficulty finding jobs even when the local labour market is strong (Holzer 1996; Centre on Budget and Policy Priorities, 1996).

The problem is that in recent years tight labour markets have been of relatively short duration, frequently followed by a recession which either wiped out previous gains for many workers or did not allow others to fully recover from a previous period of economic stagnation. It would take sustained tight labour markets over many years to draw back those discouraged inner-city workers who have dropped out of the labour market altogether, some for very long periods of time.

The United States is now in one of the longest economic recoveries in the last half century, a recovery that has lasted almost eight years and 
generated more than 14 million net new jobs and the lowest official unemployment rate in 24 years. This sustained recovery is beginning to have some positive effect on the hard-core unemployed. The ranks of those out of work for more than six months declined by almost 150,000 over a two-month period in early 1997. And, as reported in early 1998, since 1992, the unemployment rate for high school dropouts declined by five points from 12 to 7 percent and two-fifth of this decline has come in the last year (Nasar 1998).

How long this current period of economic recovery will last is anybody's guess. Some economists think that it will last for at least several more years. If it does it will be the best antidote for low-skilled workers whose employment and earning prospects have diminished in the late $20^{\text {th }}$ century. For example, in America's inner cities the extension of the economic recovery for several more years will significantly lower the overall jobless rate not only for the low-skilled workers who are still in the labour force but for those who have been outside the labour marker for many years as well. It will also enhance the job prospects for many of the welfare recipients who reach the time limit for the receipt of welfare.

But, given the decreased relative demand for low-skilled labour what will happen to all of these groups if the economy slows down. Considering the changing nature of the economy, there is little reason to assume that their prospects will be anything but bleak. Why? Simply because the economic trend that has twisted against low-skilled workers is unlikely to reverse itself, thereby diminishing over the long term their job prospects and earnings.

The growing problems facing low-skilled workers are not unique to the United States. With changes in technology and the globalisation of the economy, knowledge-based industries are growing more rapidly than other industries in the economies of western nations. While many educated workers benefit from these changes, the demand for low-skilled workers has plummeted to the lowest depths in human history.

As I have pointed out, in the United States the decreased demand for low-skilled labour has elevated jobless rates in the inner cities. Furthermore, in both the United States and Britain it has resulted in growing wage differentials between the economic haves and have nots. Outside of Britain, in most of continental Europe, wage inequality has grown more slowly because of powerful trade unions and a thicker social safety net, but the decreased demand for low-skilled labour has shown up in higher levels of unemployment.

The decline in the relative demand for low-skilled labour has had a more adverse effect on minorities (including immigrant minorities in Europe) because a substantially larger proportion are unskilled. As their jobless rates 
and related social dislocations rise, will the policy discussions to address the jobs problems focus on matters pertaining to race instead of those involving class' A brief look at recent developments in the United States may suggest an answer.

\section{Addressing Jobless Poverty in the Face of the New Racism}

National and international economic transformations have placed new stresses on families and communities in the United States - stresses that are hardly confined to blacks. Along with African-Americans, large segments of the white, Latino, Asian and Native American populations have also been plagued by economic insecurities, family break-ups, and community stresses. Such conditions are breeding grounds for racial and ethnic tensions.

In this social climate, some conservatives in the United States have attempted to unite white Americans around anger at the government and racial minorities. Their political messages seem plausible to many white taxpayers, who see themselves as being forced to pay for programmes, such as welfare for the jobless poor, that are perceived as benefiting primarily racial minorities. Why have such messages resonated with many in the white population during the 1990s, especially the first half of the 1990s?

The typical liberal response to this question is that these messages are effective because they trigger underlying feelings of American racism. Accordingly, many American liberals are pessimistic about public policy initiatives to address the inner-city jobs problem. Racism - a term frequently used, but lacking precision, in discussions of the conditions of racial minorities in the United States, especially the conditions of AfricanAmericans - should be understood as an ideology of racial domination. This ideology features two things:

(1) beliefs that a designated racial group is either biologically or culturally inferior to the dominant group, and

(2) the use of such beliefs to rationalise or prescribe the racial group's treatment in society, as well as to explain its social position and accomplishments.

This definition of racism is a modified version of an earlier definition in Wilson (1973). Feelings about the treatment of a particular racial group can range from the most extreme view that it should be denied the same rights and privileges available to the dominant group, to the milder view that the society should make no special efforts to help the group overcome its disadvantages. Regardless of how closely the view represents the extreme or the milder position on how a racial group should be treated, it is racist only if 
it is justified by beliefs that the racial group is biologically or culturally inferior. Accordingly, I identify two types of racism - biological racism and cultural racism. The use of the belief system in these two types of racism may vary depending upon the treatment that is prescribed for the racial group.

In the United States there is no question that the more categorical forms of racist ideology - that is, those that represent biological racism - have declined significantly (Bobo, Kluegel, and Smith 1997). Unlike in the Jim Crow segregation era from the late 1890s to shortly before mid-twentieth century, hardly anyone today is willing to endorse categorical beliefs in the biological inferiority of African-Americans (Bobo, Kluegel, and Smith 1997), including beliefs that blacks should be denied equal rights and privileges because they are biologically inferior or that the relative performance and social position of blacks in the United States can be explained in terms of biological capabilities. Racial ideology still prevails however. In recent years, the General Social Survey, conducted by the National Opinion Research Centre of the University of Chicago, changed the questionnaire format it had been using since 1940 to gauge racial stereotypes. In rating blacks, respondents were no longer asked to agree of disagree with 'blunt categorical assertions,' but, instead, were requested to rate blacks, whites, Hispanics and Asians using bipolar trait rating scales (Bobo, Kluegel, and Smith 1997: 30). Thus, African-Americans were compared with the other racial groups in terms of the work ethic, preference for welfare, and degree of intelligence.

These relative, as opposed to categorical, judgements reveal that:

blacks are rated as less intelligent, more violence prone, lazier, less patriotic, and more likely to prefer living off welfare than whites. Not only are whites rated more favourably than blacks, but on four of the five traits examined (except patriotism), many whites rated the majority of blacks as possessing negative qualities and the majority of whites as possessing positive qualities (Bobo and Kluegel 1997: 118).

Nonetheless, despite these negative stereotypes, over the past fifty years, there has been a steep decline in white support for racial segregation and discrimination. For example, although in 1942 only 42 percent of white Americans supported integrated schooling, by 1993 that figure had skyrocketed to 95 percent. Public opinion polls reveal similar patterns of change during the last five decades in white support for the integration of public accommodations and mass transportation and the principle of integrated residential areas (Bobo and Smith 1994).

However, the virtual disappearance of Jim Crow attitudes in support of racial segregation has not resulted in strong backing for government 
programmes to aggressively combat discrimination, increase integration, enrol blacks in institutions of higher learning, or enlarge the proportion of blacks in higher-level occupations. Indeed, as evidenced in the public opinion polls, whites overwhelmingly object to government assistance targeted to blacks. For example, 'Support for the principle of equal access to jobs stood at 97 percent in 1972 [the last time this particular question was asked]. Support for federal efforts to prevent job discrimination, however, had only reached 39 percent' (Bobo, Kluegel, and Smith 1997: 25). Whereas eight of every ten African-Americans today believe that the government is not spending enough to assist blacks today, only slightly more than one-third of white Americans feel this way. The idea that the federal government 'has a special obligation to help improve the living standard of blacks' because they 'have been discriminated against so long' was supported by only one in five whites in 1991 and has never exceeded more than one in four since 1975. And the lack of white support for this idea is unrelated to background factors such as age and education level (Bobo and Kluegel, 1993).

How much of this opposition to government programmes can be attributed to stereotypes about black cultural traits? In other words, how much of the opposition represents the milder form of cultural racism, the form of racial ideology that Lawrence Bobo and his colleagues have referred to as 'laissez-faire' racism (Bobo, Kluegel and Smith 1997; Bobo and Kluegel 1997)? In this connection, James Kluegel's study of trends in whites' explanations of the black-white economic gap revealed that throughout the period of 1977 to 1989, the most frequently stated reason for the economic gap between blacks and whites was the lack of motivation on the part of African-Americans (Kluegel 1990). In other words, African-Americans were blamed for their own poorer economic position. This prevalent denial of social responsibility and the high level of negative stereotyping in the recent General Social Surveys suggests 'that for many White Americans, blacks are viewed as undeserving of special treatment from government' (Bobo and Kluegel 1997: 119; also see Kluegel 1990; Kluegel and Smith 1983).

Conservative supporters of welfare reform implicitly communicated this message in their explanations of the high jobless and public assistance rates in the inner city and in their opposition to affirmative action programmes. Thus when American conservatives try to account for the high welfare rates of the jobless inner-city poor they maintain that it reflects the shortcomings of individuals, including their lack of work ethic. There is little or no appreciation for the harmful behavioural effects that emerge when lack of job opportunities results in persistent joblessness. This is not a problem unique to inner-city blacks. One of the earliest studies to examine the effects of persistent unemployment was conducted over fifty years ago by Marie 
Jahoda, Paul F. Lazarsfeld, and Hans Zeisel in Marienthal, a small industrial community in Austria 'at the time of a depression that was much worse than anything the United States went through.' During the period of the research, the entire community of Marienthal was unemployed. 'One of the main theses of the Marienthal study was that prolonged unemployment leads to a state of apathy in which the victims do not utilise any longer even the few opportunities left to them' (Jahoda, Lazerfeld and Zeisel 1972: vii).

Before this economic depression, when people in the community were working, political organisations were active. People of the town read a lot, 'entered eagerly into discussions, and enjoyed organising a variety of events'. The factory was at the centre of this lively community. It 'was not simply a place of work. It was the centre of social life'. (Jahoda, Lazerfeld and Zeisel 1972: vii). All of this disappeared when the factory shut down. Describing the situation during their field research in 1930, the authors stated:

Cut off from their work and deprived of contact with the outside world, the workers of Marienthal have lost the material and moral incentives to make use of their time. Now that they are no longer under any pressure, they undertake nothing new and drift gradually out of an ordered existence into one that is undisciplined and empty. Looking back over any period of this free time, they are unable to recall anything worth mentioning.

For hours on end, the men stand around in the street alone or in small groups, leaning against the wall of a house or the parapet of the bridge. When a vehicle drives through the village they turn their heads slightly; several of them smoke pipes. They carry on leisurely conversations for which they have unlimited time. Nothing is urgent anymore; they have forgotten how to hurry (Jahoda, Lazerfeld and Zeisel (1972: 66).

The idleness and lack of discipline due to persistent joblessness in Marienthal is not unlike the idleness and undisciplined behaviour associated with persistent joblessness in today's inner-city neighbourhoods. But these are not issues that cultural racists highlight when they argue against government programmes to aid the jobless poor.

However, I maintain that it would be a mistake to focus on this new form of racial ideology, however widely endorsed, when discussing the willingness of Americans to address the jobs problem in the inner city. Why? Simply because we need to consider, for social policy purposes, the extent to which situational economic and political factors mediate the effects of racial ideology. Allow me to elaborate. 


\section{How the Situational Context influences Public Policy Discussions of Jobless Poverty}

The degree of support for social policies to address racial inequality is in no small measure related to feelings of economic anxiety. Take the situation in the United States from 1990 to 1995, the period in which the country was staggering from the effects of the 1990-92 recession. The decline of real wages (that is, wages adjusted for inflation) that had begun in the early 1973 continued uninterrupted during the first half of the 1990s. Working-class Americans felt economically pinched, barely able to maintain current standards of living even on two incomes. Ten million workers held two or more jobs in 1995, a figure that had increased 70 percent since 1980. Indeed, in six million households two adults hold four jobs to make ends meet. By 1995 the time on the job for the average workers has increased 163 hours a year since 1980, or roughly an extra month a year. Work time had risen for the great majority of employed Americans - not only wall street lawyers, but hospital orderlies and assembly-line workers as well (Hewlett and West 1998).

Many were insecure about keeping their jobs. For example, a 1994 nation-wide poll revealed that 40 percent of the workers in America worried that that they might be laid off or have their wages reduced. Many feared that they will never be able to afford to send their children to college. Many believed that for all their hard work, their children's lives will be worse than theirs. For example, a 1995 Harris poll, conducted for Business Week, revealed that only half of all parents expected their children to have a better life than theirs; nearly 7 out of ten believed that the American dream has been more difficult to achieve during the past ten years; and three quarters felt that the dream will be even harder to achieve during the next ten years (cited in Bronfenbrenner et al. 1996).

This economic anxiety evident during the first half of the 1990s lingers on during the current more robust economic period, albeit in a reduced form, and perhaps explains why there has been so much worker restraint during the mid- to late-1990s in the face of a prolonged economic recovery. As I indicated previously since 1993 the US economy has added roughly 14 million jobs and the unemployment rate has declined to 4.3 percent, the lowest in thirty years. Yet, prices have not increased very much because wages, the main element of costs, have not increased much either.

Despite high levels of employment and labour shortages in some areas, workers have been surprisingly hesitant to demand higher wages. Few would have predicted that kind of behaviour in such a favourable job 
market. As the MIT economist Paul Krugman recently pointed out 'apparently the recession and initially jobless recovery left a deep mark on the national psyche' (1997: 21). Workers' confidence has been shaken by downsizing and the spectre - real or imagined - that many of their jobs can be done for a fraction of their salaries by workers in Third World countries (Krugman 1997).

In a recent survey of a random sample of the American public, 68 percent of the respondents overall and 72 percent of the non-college graduates expressed concern about the sending of jobs overseas by American companies. Commenting on this finding, the Princeton economist Alan Krueger states, 'the fact that the public is so scared of globalisation may mean that wage demands have been moderated as a result' (Krueger 1997: 7).

Workers in the United States feel that they can't rely on weak unions to bargain effectively for higher wages, and if they lose their jobs they feel compelled to take other employment soon on whatever terms they can get. 'With such a nervous and timid workforce,' states Krugman,

the economy can gallop along for a while without setting in motion a wage/price spiral. And so we are left with a paradox: we have more or less full employment only because individual workers do not feel secure in their jobs...The secret of our success is not productivity, but anxiety (Krugman, 1997: 22).

Unfortunately, During periods when people are beset with economic anxiety, they become more receptive to simplistic ideological messages that deflect attention away from the real and complex sources of their problems, and it is vitally important that political leaders channel citizens frustrations in more positive or constructive directions.

During the first half of the 1990s, a period of heightened economic anxiety, just the opposite frequently occurred. The poisonous rhetoric of certain highly visible spokespersons increased ethnic tensions and channelled frustrations in ways that divide groups in America. Instead of associating citizens' problems with economic and political changes, these divisive messages encouraged them to turn on each other - race against race, citizens against immigrants, ethnic group against ethnic group.

We must understand that ethnic and racial antagonisms are products of situations - economic situations, political situations, and social situations. Average citizens do not fully understand these complex forces. They are looking for answers as they cope with their own anxieties. Unfortunately, the most powerful and persuasive answers recently, as far as the general public is concerned, have come not from progressives who are more likely to associate the problems of these citizens with the complex changes of the late 
twentieth century. Rather they have come from conservative spokespersons with effective sound bite messages that deflect attention from the real sources of our problems - including messages that blame inner-city residents themselves for their high jobless and welfare rates.

These messages rang loud and clear in 1994 and 1995, especially in the months leading up to and following the Congressional election of 1994, when conservative Republicans gained control of the United States Congress. However, in the last two years the frequency and intensity of these messages have noticeably decreased. I think that we can thank continued improvement in the economy for that. People are still economically anxious and are still worried about their future, but public opinion polls reveal they are more satisfied with the state affairs today than they were in 1994 when the Republicans took over the United States Congress and in 1995 when conservative political leaders perceived that their messages about the adverse effects of welfare, immigration, and affirmative action programmes would resonate with the general population. Is now the time for progressives to build on this shift in the public's mood? I think so.

I am convinced that despite the new form of cultural racism, we can create a climate in the United States that could lead to a constructive dialogue on how problems associated with the disappearance of work among certain segments of our population can be addressed. It is important to appreciate, first of all, that the poor and the working classes of all racial and ethnic groups struggle to make ends meet, and that even the middle class has experienced a decline in its living standard. These groups make up about 80 percent of the American population. And unlike the top 20 percent, they are struggling. Indeed, despite improvements in the economy, these Americans, representing different racial and ethnic groups, continue to worry about unemployment and job security, declining real wages, escalating medical and housing costs, the availability of affordable child care programmes, the sharp decline in the quality of public education, and crime and drug trafficking in their neighbourhoods.

Despite being officially race-neutral, programmes created in response to these concerns - programmes that increase employment opportunities and job skills training, improve public education, promote better child and health care, and reduce neighbourhood crime and drug abuse - would disproportionately benefit the inner-city jobless poor, but they would also benefit large segments of the remaining population, including the white population as well.

United States national opinion poll results suggest the possibility of a new alignment in support of a comprehensive social rights initiative that 
would include such programmes. If such an alignment is attempted, perhaps it ought to feature a new public rhetoric that would do two things:

(1) focus on problems that afflict not only the jobless poor but the working and middle classes as well, and

(2) emphasise integrative programmes that would promote the social and economic improvement of all groups in society in need of help, not just the truly disadvantaged jobless segments of the population.

Groups ranging from the inner-city poor to working- and middle-class Americans who are struggling to make ends meet will have to be effectively mobilised in order to change the current course taken by policymakers. There is a growing awareness in America that perhaps the best way to accomplish this is through coalition politics.

Because an effective political coalition in part depends upon how the issues to be addressed are defined, I want to repeat that it is imperative that the political message underscore the need for economic and social reform that benefits all groups in need of help, not just America's minority poor. The framers of this message should be cognisant of the fact that changes in the global economy have increased social inequality and created situations which had enhanced antagonisms between different racial and ethnic groups, and that these groups, although often seen as adversaries, are potential allies in a reform coalition because they suffer from a common problem - economic distress caused by forces outside their own control.

If inner-city blacks are experiencing the greatest problems of joblessness in the United States, it is a more extreme form of economic marginality that has affected most low-skilled workers in American since 1980. Unfortunately, there is a tendency among policymakers, black leaders and scholars alike to separate the economic problems of the ghetto from the national and international trends affecting American families and neighbourhoods. If the economic problems of the ghetto are defined solely in racial terms they can be isolated and viewed as only requiring race-based solutions as proposed by those on the left, or narrow political solutions with subtle racial connotations, such as welfare reform, as strongly proposed by those on the right.

Race continues to be a factor that aggravates inner-city black employment problems. But the tendency to overemphasise the racial factors obscures other more fundamental forces that have sharply increased innercity black joblessness. As the late black economist Vivian Henderson put it several years ago, 'it is as if racism having put blacks in their economic place step aside to watch changes in the economy destroy that place' (Henderson, 1975: 54). To repeat, the concentrated joblessness of the inner-city poor represents the most dramatic form of the growing economic dislocations 
affecting many Americans that stem in large measure from changes in the organisation of the economy, including the global economy.

\section{Conclusion}

I end with this point. My reflection on the scene in American lead me to the conclusion that as Britain and other nations in Europe confront the problems of urban poverty and joblessness in the global economy, they ought to appreciate that discussions emphasising common solutions to commonly shared problems promote a sense of unity, regardless of the different degrees of severity in the problems afflicting different groups. Such messages bring ethnic and racial together, not apart, and are especially important during periods of ethnic and racial tension.

Because the problems of the new social inequality (the gap between the expanding have-nots and the haves) are growing more severe, a vision that acknowledges racially distinct problems and the need for remedies like affirmative action to address the under-representation of minorities in valued positions, but at the same time emphasises the importance of trans-racial solutions to shared problems, is more important now than ever. Such a vision should be developed, shared, and promoted by all progressive leaders, but especially by political leaders.

A new democratic vision must reject the commonly held view that race or ethnicity is so divisive that groups from different nations and ethnic backgrounds cannot work together in a common cause. Those articulating the new vision must realise that if a political message is tailored to a white audience, racial minorities draw back, just as whites draw back when a message is tailored to minority audiences. The challenge is to find issues and programs that concern the families of all racial and ethnic groups, so that individuals in these groups can honestly perceive their mutual interests and join in a multiethnic coalition to move a country forward. 


\section{References}

Bobo, Lawrence, and James R. Kluegel (1993), 'Opposition to Race Targeting: Self-Interest, Stratification Ideology, or Racial Attitudes?', American Sociological Review 58: 443-464.

Bobo, Lawrence, and James R. Kluegel (1997), 'Status, Ideology, and Dimensions of Whites' Racial Beliefs and Attitudes: Progress and Stagnation', in Racial Attitudes in the 1990s (edited by Steven A. Tuch and Jack K. Martin), 93-120. Westport, Co: Praeger.

Bobo, Lawrence, and Ryan A. Smith (1994), 'Antipoverty Politics, Affirmative Action, and Racial Attitudes', in Confronting Poverty: Prescriptions for Change (edited by Sheldon H. Danziger, Gary D. Sandefur, and Daniel H. Weinberg), 365-395. Cambridge: Harvard University Press.

Bobo, Lawrence, James R. Kluegel, and Ryan A. Smith (1997), 'Laissez-Faire Racism: The Crystallization of a Kinder, Gentler, Antiblack Ideology', in Racial Attitudes in the 1990s (edited by Steven A. Tuch and Jack K. Martin), 16-42. Westport, Co: Praeger.

Bourdieu, Pierre (1965), Travail et travailleurs en Algerie. Paris: Editions Mouton.

Bourgois, Philippe (1995), In Search of Respect: Selling Crack in El Barrio. New York: Cambridge University Press.

Bronfenbrenner, Urie, Stephen Ceci, Phyllis Moen, Peter McClelland, and Elaine Wethington (1996), The State of Americans: This Generation and the Next. New York: The Free Press.

Centre on Budget and Policy Priorities (1995), 'The Earned Income Tax Credit Reductions in the Senate Budget Resolution', Washington, DC, June 5.

Centre on Budget and Policy Priorities (1996) 'The Administration's \$3 Billion Jobs Proposal', Washington DC.

Henderson, Vivian (1975), 'Race, Economics, and Public Policy,' Crisis 83 (Fall): 50-55.

Hewlett, Sylvia Ann (1998), The War Against Parents. New York: Houghton Mifflin Co.

Holzer, Harry J. (1991), 'The Spatial Mismatch Hypothesis: What Has The Evidence Shown?', Urban Studies 28: 105-22. 
(1996), What Employers Want: Job Prospects for Less-Educated Workers. New York: Russell Sage Foundation.

Ihlanfeldt, Keith R. and David L. Sjoquist (1991), 'The Effect of Job Access on Black Youth Employment: A Cross-Sectional Analysis', Urban Studies 28: 255-265.

Jahoda, Marie, Paul F. Lazarsfeld, and Hans Zeisel (1971), Marienthal: The Sociography of an Unemployed Community. Chicago: Aldine-Atherton.

Kasarda, John D. (1993), 'Inner-City Concentrated Poverty and Neighbourhood Distress: 1970-1990', Housing Policy Debate 4(3): 253302.

Katz, Lawrence (1996), Wage Subsidies for the Disadvantaged, Working Paper 5679, National Bureau of Economic Research, Inc., Cambridge, MA.

Kluegel, James R. (1990), 'Trends in Whites' Explanations of the Gap in BlackWhite Socioeconomic Status, 1977-1989', American Sociological Review 55: 512-525.

Kluegel, James R. and Eliot R. Smith (1983), 'Affirmative Action Attitudes: Effects of Self-Interest, Racial Affect, and Stratification Beliefs of Whites' Views', Social Forces 61: 797-824.

(1986), Beliefs About Inequality: Americans' Views of What Is and What Ought to Be. New York: Aldine de Gruyter.

Krueger, Alan B. (1997), 'What's Up With Wages?' Mimeo, Industrial Relations Section, Princeton University, Princeton, New Jersey.

Krugman, Paul (1997), 'Superiority Complex', New Republic, November 3: 2022.

Nasar, Sylvia (1998), 'Jobs Juggernaut Continues Surge: 300,000 find work,' New York Times, March 7: 1A and B-14.

Schwartzman, David (1997), Black Unemployment: Part of Unskilled Unemployment. Westport, Conn: Greenwood Press.

Thurow, Lester (1995), 'The Crusade That's Killing Prosperity', American Prospect March-April: 54-59.

Venkatesh, Sudhir (1996), Private Lives, Public Housing: An Ethnography of the Robert Taylor Homes. Ph.D. dissertation, University of Chicago.

Wilson, William Julius (1973), Power, Racism, and Privilege: Race Relations in Theoretical and Sociohistorical Perspectives. New York: The Free Press. 
(1987), The Truly Disadvantaged: The Inner City, The Underclass, and Public Policy. Chicago: University of Chicago Press. (1996), When Work Disappears: The World of the New Urban Poor. New York: Alfred A. Knopf.

Zax, Jeffrey and John Kain (1992), 'Moving to the Suburbs: Do Relocating Companies Leave Their Black Employees Behind?', unpublished manuscript, Harvard University. 